\title{
Knowledge, attitude and practice of safe sex among men who have sex with men (MSM) in Nigeria
}

RG Ezomoh

From AIDS Vaccine 2012

Boston, MA, USA. 9-12 September 2012

\section{Background}

The success of the antiretroviral drugs in the late $90 \mathrm{~s}$ resulted in increase sexual risk-taking behaviors among MSM and "business as usual" attitude to sex which has resulted in the high prevalence of HIV infection. We therefore studied the knowledge, attitude and practice of safe sexual practices among men who have sex with men (MSM).

\section{Methods}

Self administered open ended questionnaire with four sections: Biodata, knowledge, Attitude and practice of safe sexual practices were administered. 8 MSM communities were selected using stratified sampling method and a key opinion leader was selected per community; the KOLs administered the questionnaire to a total of 1600 MSM (200) per community.

\section{Results}

1600 participants were recruited into this survey and all were MSM (100\%). $17 \%$ were aged 18 -20years, $65 \%$ were between the age $21-29$ years while $10 \%$ were aged $30-40$ years and $8 \%$ were over 40 years of age. $96 \%$ of our respondents had good knowledge of condom use while $39 \%$ were informed about the advantage of lubricants for anal sex. $67 \%$ admitted to inconsistent use of condom. All our participants have been involved in 3 casual relationships in the last 12 months. $78 \%$ had unprotected anal sex in the last 3 months with and $88 \%$ of them were between the $18-29$ years of age. $64 \%$ had oral sex in the last 3 months and $36 \%$ of them were between $30-40$ years.

The Initiative for Equal Rights, Lagos, Nigeria
$43 \%$ of our participants take alcoholic beverages. 11\% smoke cigarette. Only $38 \%$ of our participants knew their H.I.V status.

\section{Conclusion}

MSM have good knowledge of condom use but behavioral change is low. These findings show that more HIV counseling/testing centers need to be created for MSM. Lots of MSM need to be reached with intervention to improve knowledge of risky practices associated with high risk men, reduce high-risk sexual practices, reduce barriers to HIV/STI detection and treatment.

Published: 13 September 2012

doi:10.1186/1742-4690-9-S2-P234

Cite this article as: Ezomoh: Knowledge, attitude and practice of safe sex among men who have sex with men (MSM) in Nigeria. Retrovirology 2012 9(Suppl 2):P234.

Submit your next manuscript to BioMed Central and take full advantage of:

- Convenient online submission

- Thorough peer review

- No space constraints or color figure charges

- Immediate publication on acceptance

- Inclusion in PubMed, CAS, Scopus and Google Scholar

- Research which is freely available for redistribution

Submit your manuscript at www.biomedcentral.com/submit Ciomed Central 